\title{
簡略化推論法を適用した低次元分割における ファジィ制御性能の改善
}

\author{
非会員 林 健 一 郎 (佐賀県工業技街センター) \\ 正 員大坪 昭文 (佐賀県工業技衔センター)
}

Improvement of Control Performance for Low-Dimensional Number of

Fuzzy Labelings Applying Simplified Inference Method

Kenichiro Hayashi, Non-member, Akifumi Otsubo, Member

(Industrial Technology Center of Saga)

\begin{abstract}
One of the important concept in fuzzy control is fuzzy inference, and the "simplified inference method" which is aimed at increasing the speed of the fuzzy inference has recently been used to realize a high-speed fuzzy controller. In designing a fuzzy controller, a high dimension such as $7 \times 7$ or $5 \times 5$ partitions is frequently used for the number of fuzzy labelings. However, as the number of fuzzy labelings increases, the number of control parameters increases rapidly and tuning of the fuzzy controller becomes difficult. Therefore, a fuzzy controller is required to be partitioned into a low-dimensional number of fuzzy labelings such as $3 \times 3$ partitions.

With this in mind, first, a method of improving the control performance for a low-dimensional number of fuzzy labelings using the "simplified inference method" which enables high-speed inference is proposed in this paper. Next, the effectiveness of this improvement method is investigated based on the results of several simulations where a first-order lag system with dead time, which is a representative model for plant characteristics, is used as the controlled system.
\end{abstract}

キーワード：ファジィ制御, 簡略化推論法, 低次ファジィ分割数, 制御性能, コントロールマップ

\section{1. まえがき}

ファジィ制御はL.A.Zadehによって1965年に提檀された ファジィ理論 (1)に基づいているが, このファジィ制御に おいて重要となる概念の1つにファジィ推論が挙げられる。 現在ファジィ推論法として， E.H.Mamdaniの提案した「四in

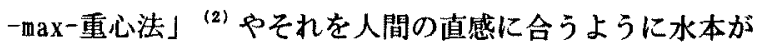
改善を施した「代数積一加算-重心法」(3) といったものが 多く用いられている。

しかし，これらのファジィ推論法は後件部メンバーシッ プ関数をファジィ集合としているため,ファジィ推論過程 における計算処理に時間を要するという問題があった。そ こで, 後件部メンバーシップ関数を非ファジィなシンダル トン型とすることにより，ファジィ推論の高速化を図った 「簡略化推論法」が市橋 ${ }^{(4)}$ や前田・村上 ${ }^{(5)}$ らによって提 案されている。

また, 現在フアジィ制御器を設計するにあたり, ファジ イ分割数として $7 \times 7$ 分割や $5 \times 5$ 分割といった高次のも のが良く使用されている。これは，一般に高次分割数にな
るほど，多種多様なファジィ制御器の非線形特性が実現し 易くなるからである。

しかし，高次分割数になるほど制御規則やメンバーシッ プ関数などの制御パラメータの数は飛躍的に增加してしま い, この傾向はファジィ制御器の入出力变数の増加に伴っ て一層顕著なものとなる ${ }^{(8)}$ 。その結果, 高次分割数にな るほど, ファジィ制御器の調整や検証は困難で時間を要す る作業となるばかりでなく, その高速化の要求をむ達成で きなくなる。

更には，現在までの報告はファジィ分割数を $7 \times 7$ 分割 のように高次とした場合の制御性能の検討がほとんどであ $\eta^{(3)}(7)-(10)$, 特に, $3 \times 3$ 分割のように低次分割数と した場合のファジィ制御器の非線形特性や制御性能の改善 について，余り娭討されていない。

以上の上うな背景から, 本論文では, ファジィ制御器の 高速化と低次元化を目的として，まず，高速推論が可能な 「簡略化推論法」を適用した低次元分割におけるファジィ 制御性能の改善について提案を行う。ここでの提案は，フ アジィ分割数が低次の $3 \times 3$ 分割の場合に,ファジィ推論 
法として「簡略化推論法」を用いた場合, その後件部のシ ンタルトン型メンバーシップ関数 $Z 0$ の高さ $h$ を調整する ことにより，制御性能が改善できるという力法である。

次に，制御規則表を規則で埋め尽くした「Ruther fordの 制御規則」 (11)，更にはファジィ制御器の一層の高速化の ために規則数を大幅に減少した「山崎・菅野の制御規 則」 ${ }^{(12)}$ に対して, シミュレーションを行った検討結果か ら本改善法の有効性を確就する。ここで, 前件部メンバー シップ関数として一般的な三角型だけでなく釣鐘型も用い, 本改善法における両者の違いを示す。なお, 制御対象とし てむた時間のある一次革れ系を 3 つのモデルに分類したも のを用いる。

最後に, ファジィ制御器の非線形特性を表すコントロー ルマップを用いて本改善法の検討を行い，ファジィ分割数 が低次の $3 \times 3$ 分割の場合でも,この高さ $h$ の調整だけで ファジイ制御器の多種多㥞な非線形特性が实現できること を示す。

\section{2. ファジィ制御系の構成と制御対象}

本シミュレーションにおけるファジィ制御系は図 1 に示 した構成であり，Eは偏差， $\Delta E$ は偏差の変化分である。 ここで, ファジィ制御器の出力は操作量 $U$ の変化分 $\Delta U$ て制御器は速度型としている。また,ファジィ制御のため の推論法として「穊略化推論法」(1) (5) を用いた。

検討した制御对象は, プラント特性の代表的なモデルで あるむだ時間のある一次遅れ系とした。そのモデルの伝達 関数は次式となる。

$$
G(s)=\frac{K \mathrm{e}^{-1,}}{1+T s}
$$

上式において，Lはむだ時間の大きさ，Tは一次遅机時 定数，Kはブラントゲインを表す。

一般に制御系設計の知識により，むだ時間のある一次遅 れ系は $L / T$ の值に応じて, 時定数が支配的な遅れ系, 中

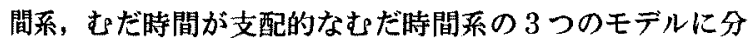
類できる(13) (14)が，ここで $L / T$ の值が大きくなるほど 制御し難い系と言われる ${ }^{(15)}$ 。本シミュレーションに拀い ては,これらのモデルを制御対象とし， $L / T$ の值が $0.1 か$ ら10の笔囲となるように, 遅れ系の場合 $L=1[\mathrm{~S}], T=$ $10[\mathrm{~S}], K=1(L / T=0.1)$, 中間系の場合 $L=1[\mathrm{~S}], T$ $=1[\mathrm{~S}], K=1(L / T=1)$, むだ時間系の場合 $L=1[\mathrm{~S}]$, $T=0.1[S], K=1(L / T=10)$ と設定した。

\section{3. 制御規則とメンバーシップ関数}

制御規則として，ファジィ分割数が低次の $3 \times 3$ 分割の 場合に，その制御規則表を全て規則で埋め尽くした 「Rutherfordの制御規則」 (1) と, 更には規則数減少のた めにその制御規則䘚に空きを設けた「山崎・菅野の制御規 則」 ${ }^{(2)}$ を用いた。これらの制御規則表をそれぞれ表 1 の (a) と(b)に示すが, ここで $3 \times 3$ 分揢とは, 前件部及び後 件部を $N B$ (Negative Big), $Z O$ (Zero) , $P B$

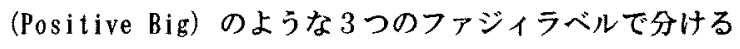
ことである。

\section{表 $13 \times 3$ 分割の場合の制御規則表}

Table 1. Control rule tables in the case of $3 \times 3$ partitions.

（a）Rutherfordの制御規則

\begin{tabular}{|l|l|l|l|}
\hline $\mathrm{AE}$ & $\mathrm{NB}$ & $Z_{0}$ & $\mathrm{~PB}$ \\
\hline $\mathrm{PB}$ & $\mathrm{Z}_{\mathrm{h}}$ & $\mathrm{PB}$ & $\mathrm{PB}$ \\
\hline $\mathrm{ZO}$ & $\mathrm{NB}$ & $\mathrm{Z}_{\mathrm{h}}$ & $\mathrm{PB}$ \\
\hline $\mathrm{NB}$ & $\mathrm{NB}$ & $\mathrm{NB}$ & $\mathrm{Z}_{\mathrm{h}} \mathrm{O}$ \\
\hline
\end{tabular}

（b）山崎・官野の制御規則

\begin{tabular}{|l|l|l|l|}
\hline$\triangle E$ & $N B$ & $Z O$ & $P B$ \\
\hline$P B$ & & $P B$ & \\
\hline$Z O$ & $N B$ & $Z_{h}$ & $P B$ \\
\hline$N B$ & & NB & \\
\hline
\end{tabular}

前件部メンバーシッブ関数としては，図 2 に示すような 通常良く使用される (a) 三角型に加えて (b) 釣鐘型を用い た $^{(18)}$ 。ここで用いたメンバーシップ関数を $A_{i}(x) \quad(i=1$ 〜3) とすると，

三角型は

$$
A_{i}(x)=\max \left[\frac{-|x-b i|+a}{a}, 0\right], a>0
$$

釣鐘型は

$$
A_{i}(x)=\exp \left[-\frac{\left(x-b_{i}\right)^{2}}{a^{2}}\right]
$$

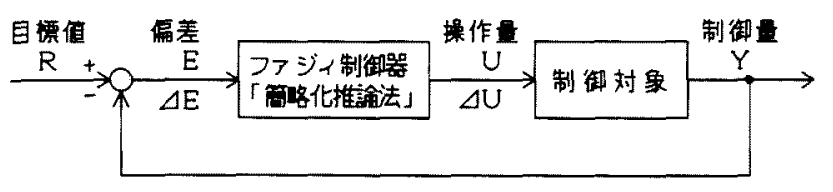

図 1 ファジィ制御系の構成

Fig. 1. Block diagram of fuzzy control system. 
ここで，biはメンバーシップ関数のグレード值が 1 にな る $x$ の值， $a$ はその広がりを表す。

なお，図 2 において隣合うメンバーシップ関数との交点 のグレード值を交叉值 $\alpha$ と呼び,

$$
\alpha=\min _{x}\left[\stackrel{3}{\vee}_{i=1}^{\vee} A_{i}(x)\right]
$$

この交叉値 $\alpha$ は，一般に良好な制御性能が得られるとの指 摘 ${ }^{(7)}{ }^{(8)}$ がある $\alpha=0.5$ に設定した。

一方, 後件部メンバーシップ関数としては, ファジィ集 合ではなく図 3 に示すような幅が零のシングルトン型 (10) を用いた。

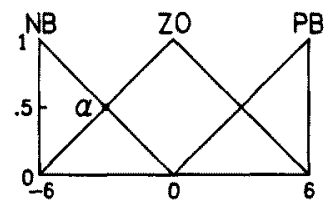

（a）三角型

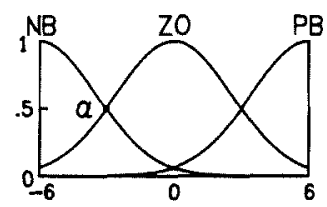

(b) 钓鐘型

図 2 前件部メンバーシップ関数

Fig. 2. Membership functions in antecedent part.

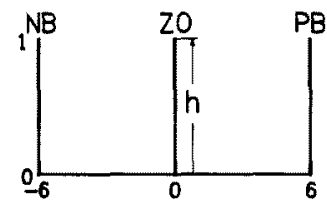

図 3 後件部メンバーシップ関数

(シンダルトン型)

Fig. 3. Membership functions in consequent part.

( Singleton Type)

\section{4. シミュレーション法と簡略化推論法}

先に著者らは，各種ファジィ推論法の構筑とその特性检 討が容易に実行できるファジィ制御用シミュレータ(17) (18) の開発を行った。本シミュレータにおけるシミュレー ション手順を図 4 に示すが，ここに活用した機能の一部を 簡単に紹介する。

まず，ファジィ分割数と制御䙺則の設定を行い，次に， 以下に示すような4つのステップでファジィ推論法の決定 を行う。

Step1：入力があった場合に, 各規則の前件部適合度を 求めるための「邂合度演算法」の設定。

Step2：各規則による推論結果を求めるための「含意演
算法」の設定。

Step3：各規則による推論結果を統合化し，規則全体と しての推諭結果を求めるための「統合化法」の 設定。

$S t e p 4 ：$ 規則全体としての推論結果を非ファジィ化し， 出力を求めるための「非ファジィ化法」の設定。 そして,メンバーシップ関数と規格化定数の設定後, 制御

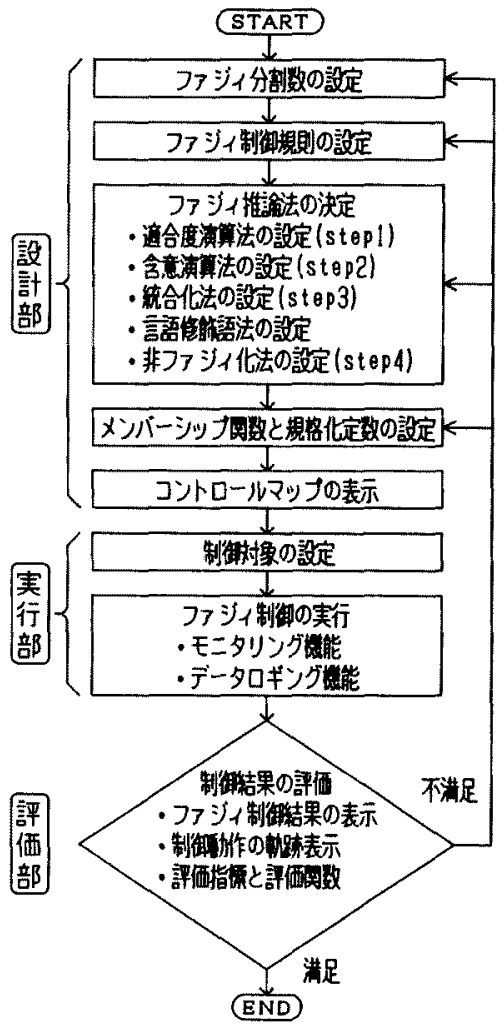

図4 ファジィ制御用シミュレータにおける

$$
\text { シミュレーション手順 }
$$

Fig. 4. Simulation procedure of fuzzy control simulator.
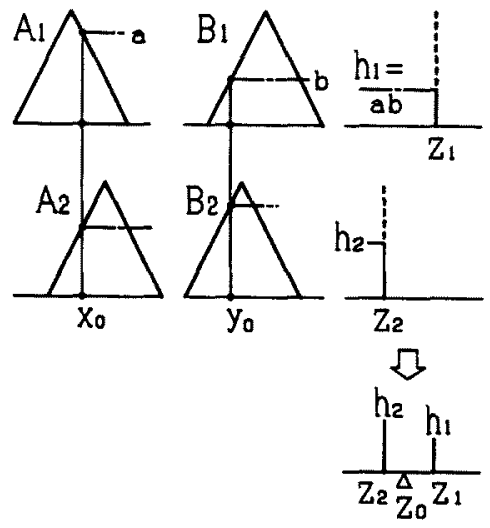

図5「簡略化推論法」における推論過程

Fig. 5. Inference process of "simplified inference method". 
对象を設定しファジィ制御シミュレーションを寒行する。

「簡略化推論法」(4) (5)（別名「代数積一加算一高さ法」） は、図 3 に示したように後件部メンバーシップ関数を非フ アジィなシングルトン型とすることにより，ファジィ推論 過程における計算処理の大幅な高速化を図ったものである。 図5に「簡略化推論法」における推論過程 ${ }^{(10)}$ を示すが, この推論過程では, ファジィ推論法の決定のStep1, 2にお いて代数積 $(X)$ 演算を設定し, Step3，4で高さ法 ${ }^{(8)}$ (重 み付き加算平均）を設定するものである。ここで，Ai， $B_{i}(i=1,2)$ は前件部のファジィ集合, $h_{i}$ は各規則の前 件部適合度， $\boldsymbol{z}$ 仙後件部のシングルトン型の位置を表す。 また， $x_{0} ， y_{0}$ 性観測值である確定值入力, $z_{0}$ 惟論結 果である非ファジィな出力を表す。

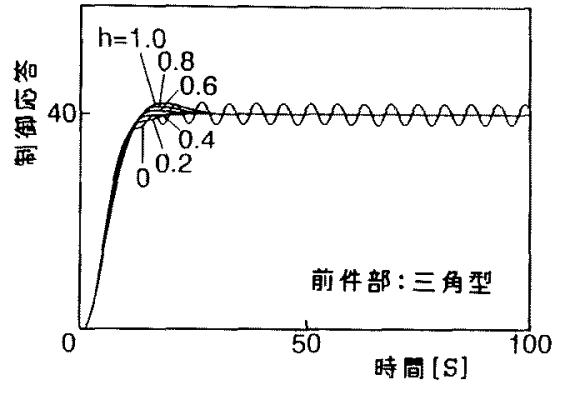

(a) 運n系 $\mathrm{L}=1$ [S], $\mathrm{T}=10[\mathrm{~S}], \mathrm{K}=1 \quad(\mathrm{~L} / \mathrm{T}=0.1)$
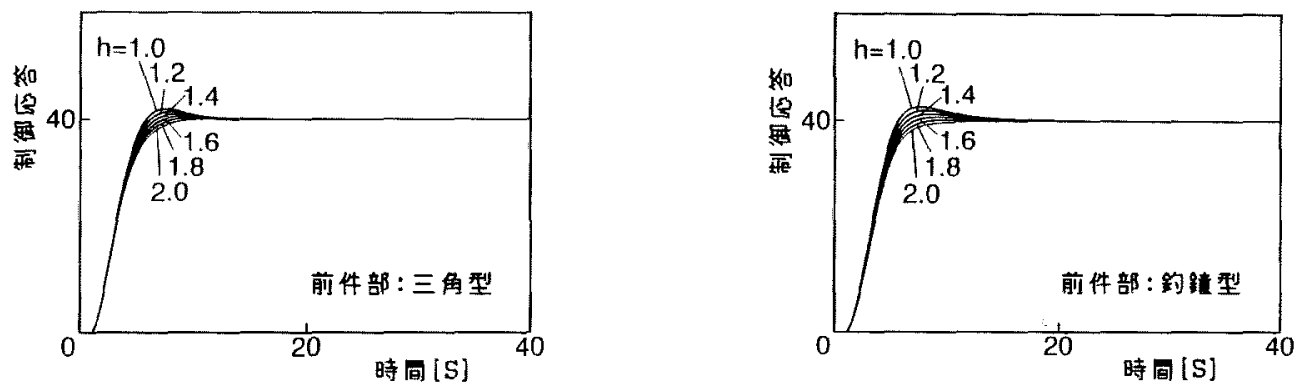

(b) 中间系 $\mathrm{L}=1[\mathrm{~S}], \mathrm{T}=1[\mathrm{~S}], \mathrm{K}=1(\mathrm{~L} / \mathrm{T}=1)$
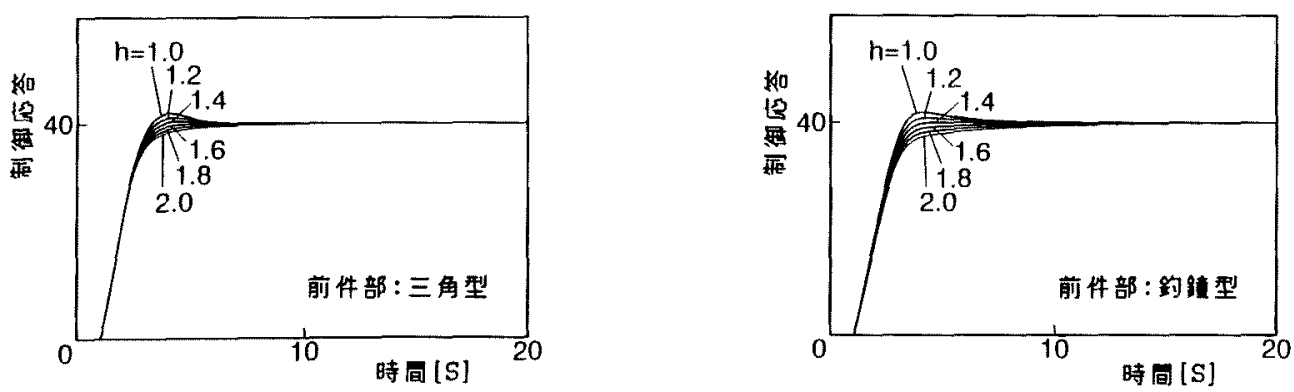

(c) むだ時同系 $L=1[S], T=0.1[S], K=1 \quad(L / T=10)$

図 6 後件部シングルトン型 $Z 0$ の高さ $h$ を変化させた場合の制御結果

(「Rutherfordの制御規則」の場合)

Fig. 6. Control results for various values of the height $h$ of singleton type $Z O$ in consequent part ( in the case of "Rutherford's control rule" ). 
$Z O$ の高さhの調整法によって制御性能の改善が図れるこ とを示す。

〈5・1〉制御規則表を埋め尽くした堨合本節では， まず，表 1 (a)の制御規則表を規則で埋め尽くした 「Rutherfordの制御規則」 ${ }^{(1)}$ に对して，この高さ $h$ の調 整法の適用で制御性能が改善できることを示す。図6は， 「Ruther fordの制御規則」を用いた場合に，後件部のシン ダルトン型 $Z O$ の高さ $h$ を変化させた場合の制御結果を示 したものである。

図 6 (a) 遅れ系では, シングルトン型 $Z 0$ の高さ $h$ を 1 かららさくして, その制御への貢献度を「狮制」 $(0 \leqq h$

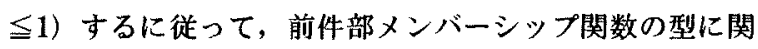
わらず制御結果は改善されている。具体的にはシングルト
ン型 ZOの貢献度の「抑制」に従って，一般には相反する 傾向を示すものであるが，ここでは立ち上がり特性とオー バーシュート量が同時に改善される結果となっている。前 件部メンバーシップ関数が三角型の場合には，ある高さ $h$ でハンチング (持続振動) が起こり不安定となっている。 一方，釣鐘型の場合には $h=0$ の場合でも制御が可能とな っている。

図6(b) 中間系と (c) むだ時間系では，遅れ系の場合とは 逆にシングルトン型 $Z O$ の高さ $h$ を 1 から大きくして，そ

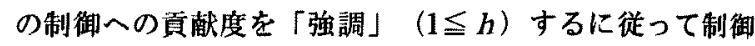
結果は改善されている。前件部メンバーシッブ関数が鈞鏡 型の場合には， $h$ を大きくするに従ってオーバーシュート 量は改善されていくが，逆に立ち上がり特性は若干悪くな
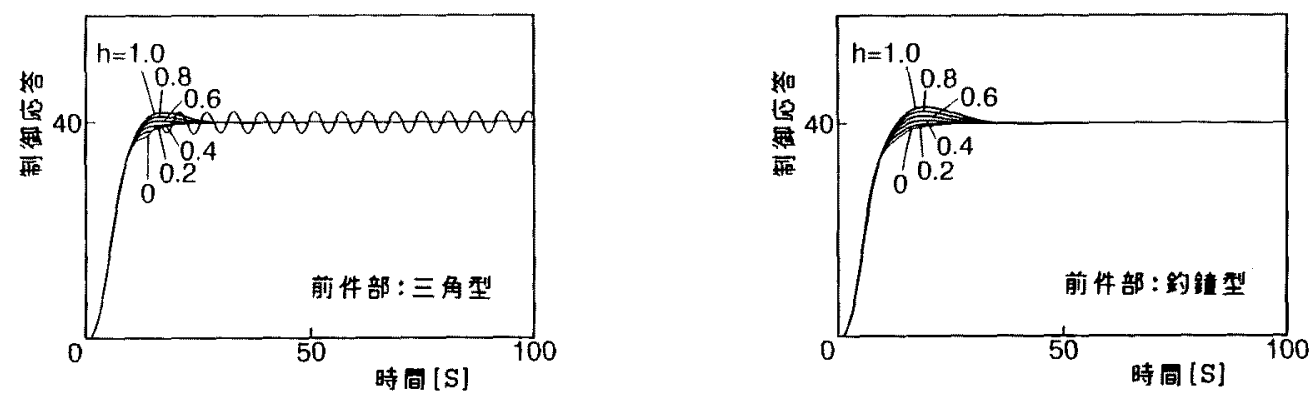

(a) 逴n系 $\mathrm{L}=1[\mathrm{~S}], \mathrm{T}=10[\mathrm{~S}], \mathrm{K}=1 \quad(\mathrm{~L} / \mathrm{T}=0.1)$
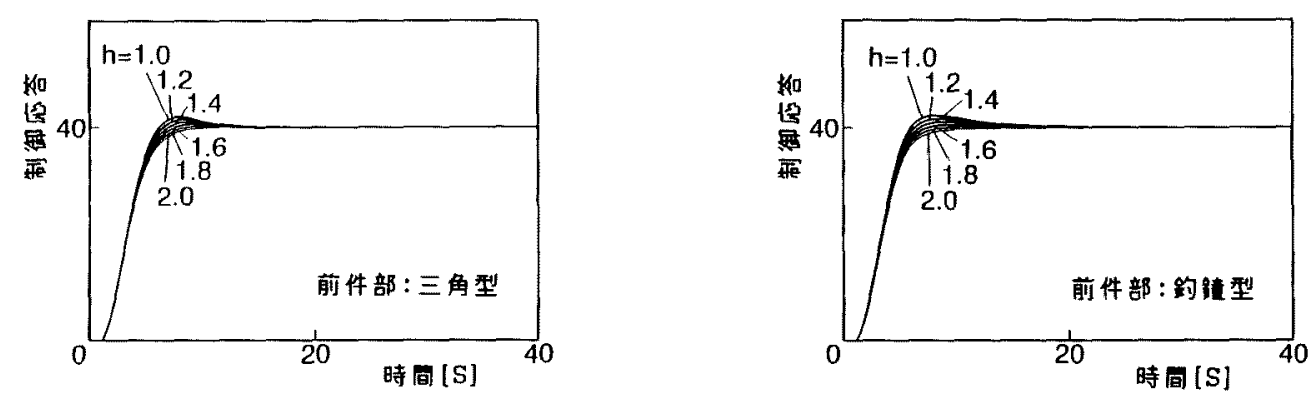

(b) 中间系 $\mathrm{L}=1[\mathrm{~S}], \mathrm{T}=1[\mathrm{~S}], \mathrm{K}=1(\mathrm{~L} / \mathrm{T}=1)$
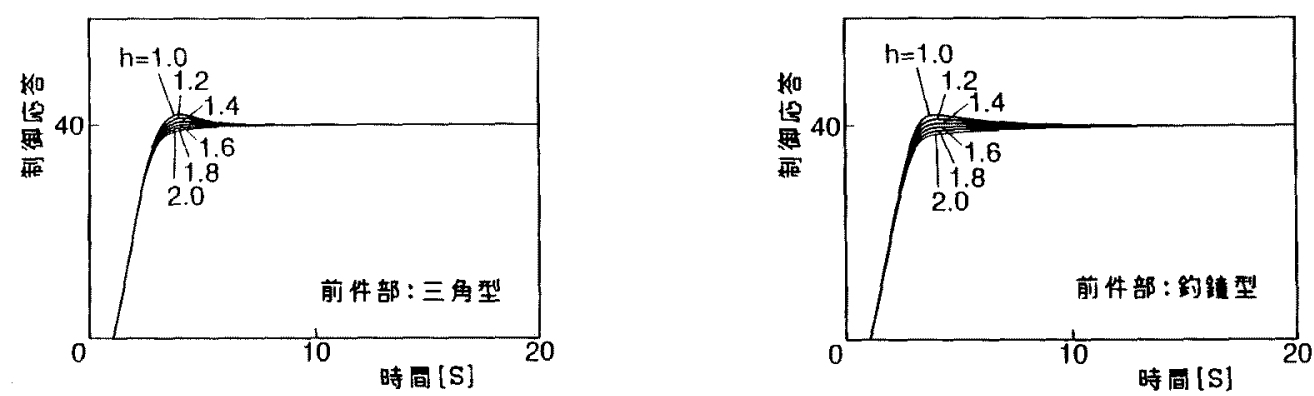

(c) むだ時间系 $\mathrm{L}=1[\mathrm{~S}], \mathrm{T}=0.1[\mathrm{~S}], \mathrm{K}=1(\mathrm{~L} / \mathrm{T}=10)$

図 7 後件部シングルトン型 $Z O$ の高さ $h$ を変化させた場合の制御結果

(「山崎・菅野の制御規則」の場合)

Fig. 7. Control results for various values of the height $h$ of singleton type $Z O$ in consequent part ( in the case of "Yamazaki \& Sugeno's control rule"). 
っている。一方，三角型の場合には，立ち上がり特性の良 さは保ったまま，オーバーシュート量を大幅に改善するこ とができ，良好な制御結果となっている。

〈5.2〉規則数を大幅に娍少した场合 本節では，更 にファジィ制御器の一層の高速化を目的として，規則数を 9 個から5個の約半分に減少した表 1 (b)の「山崎・菅野 の制御規則」(12)に対しても，この高さ $h$ の調整法の適用 で制御性能が改善できることを示す。図 7 は，「山崎・菅 野の制御規則」を用いた場合に，後件部のシンダルトン型 20 の高さ $h$ を変化させた場合の制御結果を示したもので ある。

図 7 から分かるように,この規則数を大幅に減少した 「山崎・菅野の制御規則」の場合も，図 6 に示した 「Rutherfordの制御規則」の場合の制御結果と同様に, シ ンダルトン型 $Z O$ の高さ $h$ の調整法を適用することで，モ テルが (a) 遅れ系の場合にはシングルトン型 $Z O$ の高さ $h$ を1から小さくし，その制御への貢献度を「抑制」するこ とによって，モデルが (b) 中間系や (c) むだ時間系の場合に は，逆にシングルトン型 ZO の高さ $h$ を 1 から大きくし， その制御への貢献度を「強調」することによって, 制御性 能が改善できる。

以上, $5 \cdot 1,5 \cdot 2$ 節において述べてきたように, シング ルトン型 $Z O$ の宲さ $h$ の調整法の特徵は, 一般的な規格化

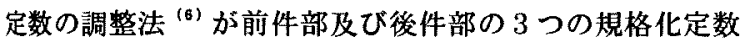
の変更を要する（図1に示したファジィ制御系の場合）の に比べ, 1 つのパラメータhの変更によって, 遅れ系, 中 間系, むだ時間系のどのモデルに对してむ制御性能の改善 を図ることができる点にある。ここでは, 立ち上がり特性
の良さは保ったままオーバーシュート量を大幅に低減でき る。

〈5・3〉 コントロールマップにおけろ検討＼cjkstart本節では， コントロールマップを用いてこの高さ $h$ の調整法の特徴を 考察してみよう。コントロールマッブはファジィ制御器の 非線形なゲイン特性を三次元的に示すむの ${ }^{(19)}$ で，その形 状からファジィ制御系の挙動をある程度予测することがで きる(20)。

図 8は，制御規則表を規則で埋め尽くした「Rutherford の制御規則」 ${ }^{(1)}$ において, 前件部メンバーシップ関数が 三角型と釣鐘型の場合に, 高さ $h$ の值を $0.4,0.2,0$ と小 さくして, 後件部のシングルトン型 $Z O$ を「抑制」した場 合のコントロールマップを示したむのである。

図 8 から分かるように, シングルトン型 $Z 0$ の高さ $h$ が 小さくなるに従って, コントロールマップの原点近傍の形 状は前件部メンバーシッフ関数が (a) 三角型の場合いびつ なものとなるが, (b) 釣鐘型の場合には $h=0$ の場合でも極 めて滑らかに形成されている。徉って, 図 6 (a) 遅れ系の 場合の制御結果で示したように，前件部メンバーシップ関 数が鈎鐘型の場合，hの值が零に近づいた場合でも制御が 可能になることが, このコントロールマップの形状からも うかがえる。

更には，「Rutherfordの制御規則」を用いた場合に, 後 件部のシングルトン型 $Z O$ の高さ $h$ を変化させた場合のコ ントロールマッブを斜めに, その非線形なゲイン特性の変 化が最も顕著に現れる $\Delta U$ 軸と直線 $E=\Delta E$ を通る平面 で切った場合の断面図を図 9 に示す。同図(a) は高さ $h$ を 1 から小さくし後件部のシングルトン型 $Z O$ を「抑制」した
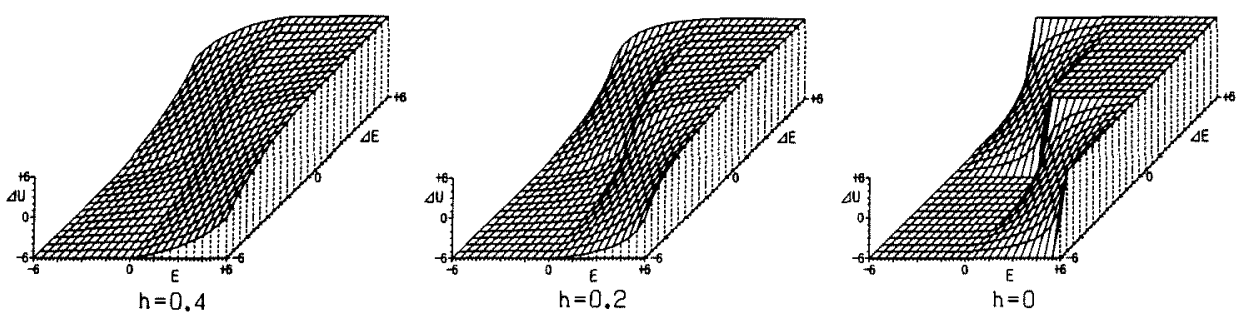

（a）前件部：三角型
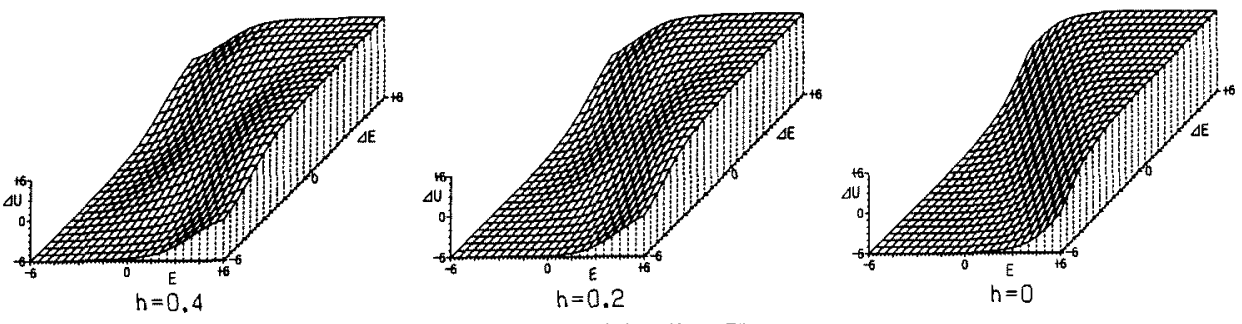

(b) 前件部：的程型

図 8 後件部シングルトン型 $Z O$ の高さ $h$ を小さくした場合のコントロールマップ

(「Rutherfordの制御規則」の場合)

Fig. 8. Control maps obtained when decreasing the height $h$ of singleton type $Z O$ in consequent part (in the case of "Rutherford's control rule"). 
場合の, 同図 (b) は高さ $h$ を 1 から大きくし後件部のシン ダルトン型ZOを「強調」した場合のコントロールマップ の断面図を示したむのである。

この図から，ファジィ分割数が低次の $3 \times 3$ 分割の場合 でも，この高さ $h$ の調整のみで, 多種多様な非線形なゲイ ン特性を有するコントロールマッブが実現できることが分 かる。

すなわち，図6に示した「Rutherfordの制御規則」を用 いた場合の制御結果において，モデルが(a)遅れ系のよう に時定数が支配的な場合には，後件部のシングルトン型 $Z O$ を「抑制」することにより，その非線形なゲイン特性 を大きくした場合のコントロールマッブを，一方，(b) 中 間系や (c)むだ時間系のようにむだ時間が支配的になって きた場合には，逆に後件部のシングルトン型ZOを「強調」 することにより，その非線形なゲイン特性を小さくした場 合のコントロールマップを適用することにより，制御性能 の改善を行った。

なお，本節では，制御規則表を規則で埋め尽くした 「Ru ther fordの制御規則」を用いた場合のコントロールマ ップにおいて，シンダルトン型 $Z O$ の高さ $h$ の調整法の検 討を行った。規則数を大幅に減少した「山崎・菅野の制御 規則」 ${ }^{(2)}$ を用いた場合にも，「Rutherfordの制御規則」 を用いた場合とほとんど同様なコントロールマップの形状 と断面図が得られ，ここでの検討と同侎な考察を行うこと ができる。

\section{6.むすひ}

本論文では，まず，ファジィ分割数が低次の $3 \times 3$ 分割 の場合に，ファジィ推論法として高速推論が可能な「簡略 化推論法」 (4) (5) を適用した場合, その後件部のシングル トン型メンバーシップ関数 $Z 0$ の高さ $h$ を調整することに よって，制御性能が改善できるという方法を提案した。

次に，制御詨象としてむだ時間のある一次遅れ系を設定 し，まず制御規則表を規則で埋め尽くした「Rutherfordの 制御規則」(11)，更には一㸴の高速化のために規則数を大 幅に減少した「山㱦・营野の制御規則」 ${ }^{(12)}$ に対して行っ た各種シミュレーション結果から, 本改善法の有効性を検 証した。

最後に, コントロールマップを用いた本改善法の検討に おいて，ファジィ分割数が低次の $3 \times 3$ 分割の場合でも， この高さ $h$ 調整だけで, 多種多様なファジィ制御器の非 線形特性が実現できることを示した。

抒わりに，本研究を遂行するにあたりご指導いただいた 九州工業大学工学部の村上周太教授, 前田幹夫助教授らに 深く謝意を表します。また，本研究は佐賀県先端重要技微 研究開発事業の実用技術共同研究の助成を得て実施した。 ここに記して，関係各位に厚くお礼申し上げます。

(平成 9 年 1 月 23 日受付, 平成 9 年 5 月 26 日再受付)

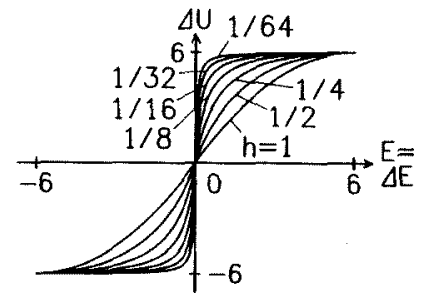

前件部:三角型

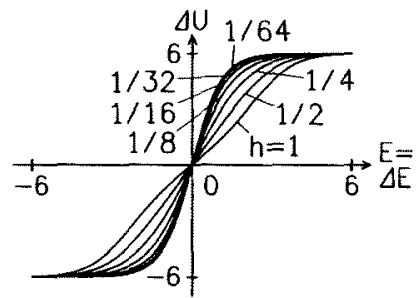

前件部: 钧䛨型

（a）毫さhを小さくしシングルトン型ZOを「抑制」した場合

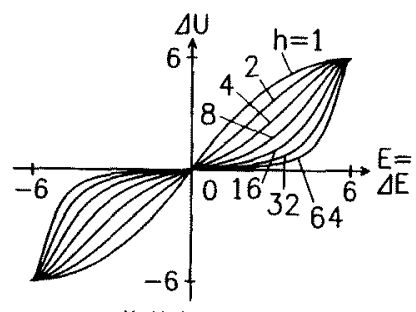

前件部:三角型

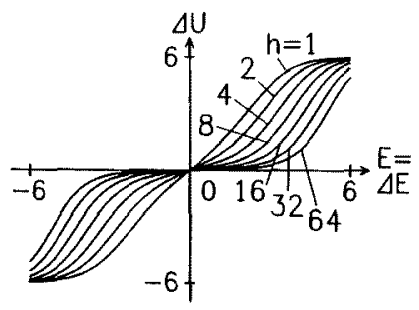

前件部：跑泣型

（b）亮さhを大きくしシングルトン型ZOを「强調」した場合

図 9 後件部シングルトン型 $Z 0$ の高さ $h$ を変化させた場合のコントロールマップの 䉼面图 (「Rutherfordの制御規則」の場合)

Fig. 9. Cross sections of control maps for various values of the height $h$ of singleton type 20 in 'consequent part ( in the case of "Rutherford's control rule" ). 


\section{文献}

(1) L. A. Zadeh: "Fuzzy Sets", Information and Control, 8, $338 \sim 358$ (1965)

(2) E. H. Mamdani: "Applications of Fuzzy Algorithms for Control of Simple Dynamic Plant", Proc. of IEE, 121, $12,1585 \sim 1588$ (1974)

（3）水本雅晴：「ファジィ制御の改善法IV（代数積一加算 一重心法による場合）」，第6回ファジィシステムシ ンポジウム講演論文集, 9〜13 (平2)

（4）市橋秀友・田中英夫：「P I D と F U Z Z Y のハイ フリッド型コントローラ」, 第4回ファジィシステム シンポジウム講演論文集, 97 102 (昭63)

（5）前田幹夫・村上周太：「ファジィ制御とその応用」, システム/制御／情報，34，5，282 287 (平2)

（6）寺野寿郎他：「実用ファジィ制御技術」, 電子情報 通信学会, $45 \sim 46,98 \sim 110$ (平3)

（7）水本雅晴：「ファジィ制御の改善法 I」, 第3回ファ ジィシステムシンボジウム講演論文集, 153 158 (昭62)

（8）水本雅晴：「ファジィ制御の改善法II」, 第4回ファ ジィシステムシンポジウム講演論文集, $91 \sim 96$ (昭63)

（9）水本雅晴：「ファジィ制御の改善法III」, 第5回ファ ジィシステムシンポジウム講演論文集，499 504 (平元)

(10）水本雅晴：「ファジィ制御の改善法VI（シングルト ン型ファジィ推論法による場合)」，第8回ファジィ システムシンポジウム講演論文集，529～533 (平4)

(11) M. Brrae and D. A. Rutherford: "Theoretical and Linguistic Aspect of the Fuzzy Controller", Automatica, $15,533 \sim 577$ (1979)

(12）山崎束・菅野道夫：「ファジィ制御」，システムと 制御， 28，7，442 446（昭59）

(13) T. Iwasaki and A. Morita: "Fuzzy Auto Tuning for PID Controller with Model Classification", Proc. of NAFIPS'90, $90 \sim 93$ (1990)

(14) 岩崎隆至・森田温・丸山寿一：「制御対象のクラス 分けを付加したファジィオートチューニング」，日 本ファジィ学会誌，5，3，639６49 (平5)

(15) 松山裕：「温度の測定と制御」, (財)省エネルギー センター, 124 128 (平元)

（16）菅野道夫：「ファジィ制御」，日刊工業新聞社， 76 $\sim 84$ (昭63)

(17) K. Hayashi, I. Muta, T. Hoshino and A. Otsubo: "Simulator for Evaluation of Various Fuzzy Control Methods", Proc. of Fifth IFSA World Congress, 949 952 (1993)

（18）林健一郎・大坪昭文：「各種ファジィ制御法の評価 用シミュレータ」, 日本ファジィ学会誌, 6, 2, 260 $\sim 264$ (平6)

(19) 張徜敦・荒木光彦：「ファジィ制御系の数理的解析 と産業応用の可能性について」, 計測自動制御学会 論文集, 26,11, 1267 1274（平2)

(20) 前田幹夫・福宮英二・坪根目弘：「非線形スケーリ ングファクタとそのファジィ制御への応用」, 第8回 ファジィシステムシンポジウム講演論文集, 549 552 (平 4 )

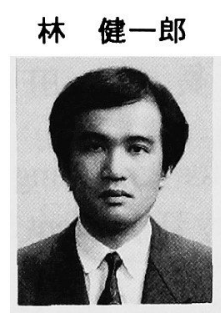

(非会員) 1954年9月9日生。1978年九州大 学工学部動力機械工学科卒業。1981年佐賀 県工業技術センターに入所。1991年佐賀大 学大学院電気工学専攻修士課程, 1994年同 大学院博士課程を修了。工学博士。主とし て, ファジィ制御などの知的制御技術を用 いた自動化システムの研究に従事。計測自 動制御学会, 日本ファジィ学会などの会員。

大坪 昭文 （正員）1965年11月4日生。1988年佐賀大 学理工学部電子工学科卒業後, 同年佐賀県 工業技術センターに入所。1995年九州工業 大学大学院電気工学専攻博士課程に社会人 入学し, 現在に至る。主としてファジィ制 御, ニューラル制御などを用いた知的制御 システムの研究に従事。電気学会, 計測自 動制御学会などの会員。 